\title{
Tissue plasminogen activator (tPA) in the management of predominantly hemorrhagic age-related macular degeneration, milligram/milliliter or microgram/milliliter?
}

This article was published in the following Dove Press journal:

Clinical Ophthalmology

18 January 2012

Number of times this article has been viewed

\section{Niels Willem Boone \\ Roelof Wouter Frederik van Leeuwen}

Maastricht University Medical Centre, Department of Clinical Pharmacy and Toxicology, Maastricht, The Netherlands
Correspondence: Niels Willem Boone Maastricht University Medical Centre, Department of Clinical Pharmacy and Toxicology, P. Debyelaan 25, 6202 AZ, Maastricht, The Netherlands

$\mathrm{Tel}+3$ I 433876723

Fax +3| 43 387473।

Email n.boone@mumc.nl
Recently our hospital pharmacy, which serves an academic hospital with an internationally well-known department of ophthalmology, received a request for the aseptic preparation of an alteplase syringe solution for subretinal administration. Looking for dose rationale, our ophthalmology doctor came up with a concentration based on an article published by Arias and colleagues in Clinical Ophthalmology in 2010. ${ }^{1}$ This article is on subretinal alteplase administration for hemorrhagic age-related macular degeneration. In the methods section, a concentration of $125 \mathrm{mg} / \mathrm{mL}$ alteplase was declared, which we found peculiar. This concentration cannot be acquired with the commercially available preparation (which has a maximum concentration of $2 \mathrm{mg} / \mathrm{mL}$ ), and could lead to undesirable side effects. In the literature, it is stated that an alteplase dose should be in the range of $200 \mu \mathrm{g} / \mathrm{mL} .{ }^{2}$ Did the authors mean $125 \mu \mathrm{g} / \mathrm{mL}$ ?

\section{Disclosure}

The authors declare no conflicts of interest in this work.

\section{References}

1. Arias L, Monés J. Transconjunctival sutureless vitrectomy with tissue plasminogen activator, gas and intravitreal bevacizumab in the management of predominantly hemorrhagic age-related macular degeneration. Clin Ophthalmol. 2010;18(4):67-72.

2. Treumer F, Klatt C, Roider J, Hillenkamp J. Subretinal coapplication of recombinant tissue plasminogen activator and bevacizumab for neovascular age-related macular degeneration with submacular haemorrhage. Br J Ophthalmol. 2010;94(1):48-53.

\section{Publish your work in this journal}

Clinical Ophthalmology is an international, peer-reviewed journal covering all subspecialties within ophthalmology. Key topics include: Optometry; Visual science; Pharmacology and drug therapy in eye diseases; Basic Sciences; Primary and Secondary eye care; Patient Safety and Quality of Care Improvements. This journal is indexed on
PubMed Central and CAS, and is the official journal of The Society of Clinical Ophthalmology (SCO). The manuscript management system is completely online and includes a very quick and fair peer-review system, which is all easy to use. Visit http://www.dovepress.com/ testimonials.php to read real quotes from published authors. 